\title{
Cannabinoid Receptor Interacting Protein 1a (CRIP1a): Function and Structure
}

\author{
William T. Booth ${ }^{1}\left(\mathbb{D}\right.$, Noah B. Walker ${ }^{2} \mathbb{D}$, W. Todd Lowther ${ }^{1,3}\left(\mathbb{D}\right.$ and Allyn C. Howlett ${ }^{3,4, *}$ \\ 1 Department of Biochemistry and Center for Structural Biology, Wake Forest School of Medicine, \\ Medical Center Blvd., Winston-Salem, NC 27157, USA; wbooth@jcsu.edu (W.T.B.); \\ tlowther@wakehealth.edu (W.T.L.) \\ 2 Department of Physiology and Pharmacology, Wake Forest School of Medicine, Medical Center Blvd., \\ Winston-Salem, NC 27157, USA; nbwalker@wakehealth.edu \\ 3 Center for Molecular Signaling, Wake Forest University, 1834 Wake Forest Road, \\ Winston-Salem, NC 27109, USA \\ 4 Department of Physiology and Pharmacology, Center for Research on Substance Use and Addiction, \\ Wake Forest School of Medicine, Medical Center Blvd., Winston-Salem, NC 27157, USA \\ * Correspondence: ahowlett@wakehealth.edu; Tel.: +01-336-716-8545
}

Received: 17 September 2019; Accepted: 8 October 2019; Published: 12 October 2019

\begin{abstract}
Cannabinoid receptor interacting protein 1a (CRIP1a) is an important $\mathrm{CB}_{1}$ cannabinoid receptor-associated protein, first identified from a yeast two-hybrid screen to modulate $\mathrm{CB}_{1}$-mediated $\mathrm{N}$-type $\mathrm{Ca}^{2+}$ currents. In this paper we review studies of CRIP1a function and structure based upon in vitro experiments and computational chemistry, which elucidate the specific mechanisms for the interaction of CRIP1a with $\mathrm{CB}_{1}$ receptors. N18TG2 neuronal cells overexpressing or silencing CRIP1a highlighted the ability of CRIP1 to regulate cyclic adenosine $3^{\prime}, 5^{\prime}$ monophosphate (cAMP) production and extracellular signal-regulated kinase (ERK1/2) phosphorylation. These studies indicated that CRIP1a attenuates the $\mathrm{G}$ protein signaling cascade through modulating which Gi/o subtypes interact with the $C B_{1}$ receptor. CRIP1a also attenuates $C_{1}$ receptor internalization via $\beta$-arrestin, suggesting that CRIP1a competes for $\beta$-arrestin binding to the $\mathrm{CB}_{1}$ receptor. Predictions of CRIP1a secondary structure suggest that residues 34-110 are minimally necessary for association with key amino acids within the distal C-terminus of the $\mathrm{CB}_{1}$ receptor, as well as the $\mathrm{mGlu}_{8 \mathrm{a}}$ metabotropic glutamate receptor. These interactions are disrupted through phosphorylation of serines and threonines in these regions. Through investigations of the function and structure of CRIP1a, new pharmacotherapies based upon the CRIP-CB $B_{1}$ receptor interaction can be designed to treat diseases such as epilepsy, motor dysfunctions and schizophrenia.
\end{abstract}

Keywords: adenylyl cyclase; $\beta$-arrestin; computational chemistry; CP55940; cyclic adenosine $3^{\prime}, 5^{\prime}$ monophosphate (cAMP); extracellular signal-regulated kinase (ERK); G proteins; G protein coupled receptor (GPCR); WIN55212-2

\section{Introduction}

Cellular signaling via the $\mathrm{CB}_{1}$ cannabinoid receptor has been predicated upon the understanding that $\Delta^{9}$-tetrahydrocannabinol (THC) is the primary psychoactive compound in Cannabis (reviewed in [1]), and that $\Delta^{9}$-THC analogs serve as agonists to promote $\mathrm{G}$ protein activation. Signal transduction occurs via Gi/o-mediated inhibition of adenylyl cyclase for agonist analogs of $\Delta^{9}-\mathrm{THC}$, such as CP55940, prototypical of a series of cannabimimetic analgesics developed by Pfizer (reviewed in [2]). WIN55212-2 and its analogs are amino-alkylindole agonists for the $\mathrm{CB}_{1}$ receptor [2]. The $\mathrm{CB}_{1}$ receptor is a $\mathrm{G}$ protein-coupled receptor (GPCR) for the endogenous eicosanoids N-arachidonylethanolamide and 2-arachidonoylglycerol, and some structurally homologous lipid mediators (reviewed in $[3,4]$ ). 
In addition to $\mathrm{Gi} / \mathrm{o}-$ mediated inhibition of adenylyl cyclase, $\mathrm{CB}_{1}$ agonists also release $\mathrm{G} \beta \gamma$ subunits to inhibit various $\mathrm{Ca}^{2+}$ channels. $\mathrm{CB}_{1}$ agonists also promote complex interactions with receptor tyrosine kinases and non-receptor src kinases to activate the extracellular signal-regulated kinase (ERK1/2) and other regulatory kinases $[2,5]$. In addition to $G$ proteins, the $C_{1}$ receptor interacts with $\beta$-arrestins, which serve as regulators of cellular signaling or receptor trafficking [6,7].

Cannabinoid receptor interacting protein 1a (CRIP1a) was sought and discovered as a result of findings by the Deborah Lewis laboratory that deletion of the distal C-terminal amino acids augmented the $\mathrm{CB}_{1}$ receptor constitutive inhibition of the voltage-dependent $\mathrm{Ca}^{2+}$ current in superior cervical ganglion neurons, suggesting that the distal C-terminal domain performed an inhibitory function $[8,9]$. Reasoning that the $\mathrm{C}$-terminal binds to a regulatory protein, the Lewis laboratory performed a yeast two-hybrid screen which identified CRIP1a as a key $\mathrm{CB}_{1}$ receptor-associated protein $[9,10]$. They demonstrated that heterologous expression of CRIP1a could attenuate constitutive inhibition of $\mathrm{N}$-type $\mathrm{Ca}^{2+}$ channels by exogenously expressed $\mathrm{CB}_{1}$ receptors in superior cervical ganglion neurons [10]. This finding suggests that $G \beta \gamma$ release can be attenuated in the presence of CRIP1a. Co-immunoprecipitation of CRIP1a with $\mathrm{CB}_{1}$ receptors demonstrated that these two proteins form a complex in 3-[(3-cholamidopropyl)dimethylammonio]-1-propanesulfonate (CHAPS) detergent-solubilized rat brain membranes [10]. Deletion mapping studies demonstrated that the distal C-terminal nine amino acids of the $\mathrm{CB}_{1}$ receptor constituted the minimum domain required for CRIP1a binding [10].

The purpose of the present review is to describe the unique interactions that CRIP1a can have with the $C_{1}$ receptor to regulate cellular signaling and $C_{1}$ receptor trafficking. Regulation of $C_{1}$ receptor activity by CRIP1a can be investigated at both the functional and structural levels with the goal of designing peptide or small molecule drugs that can selectively target the CRIP1a-CB receptor interaction for therapeutic intervention in the treatment of pain, convulsions [11-14], schizophrenia $[15,16]$, and neurodegenerative motor disorders [17].

\section{Functional Modulation of $\mathrm{CB}_{1}$ Cellular Signaling by CRIP1a}

Our laboratory has performed studies with N18TG2 neuroblastoma cell clones that endogenously express $\mathrm{CB}_{1}$ receptors, $C R I P 1 \mathrm{a}, \mathrm{G}$ proteins, and other associated proteins as a model to investigate neuronal cell signaling and to provide insight into the interactions of these proteins in their native environment [18-20]. Using stable CRIP1a-overexpressing and CRIP1a-siRNA-silenced knockdown clones, we can manipulate these proteins in CRIP1a gene dose experiments to determine how these incremental increases or decreases in CRIP1a modulate the endogenous system. This model is superior to use of non-neuronal host cells (e.g., $\mathrm{COS}, \mathrm{HEK}, \mathrm{CHO}$ ) that do not exhibit a neuronal phenotype and fail to express some or all of the native system components.

\subsection{G Protein Selectivity and Effect on Signal Transduction Via cAMP Inhibition and ERK1/2 Phosphorylation}

Studies in cell culture models have demonstrated that CRIP1a over-expression attenuates $\mathrm{CB}_{1}$ receptor signaling via $G$ proteins $[18,21]$. As quantitated by antibody-capture scintillation proximity $\left[{ }^{35} \mathrm{~S}\right.$ guanosine $5^{\prime}$-O-[gamma-thio]triphosphate (GTP $\left.\gamma \mathrm{S}\right)$ binding assays, CRIP1a influences the subtype of Gi/o protein that can be activated by agonists [18]. Over-expression of CRIP1a attenuated CP55940-activation of Gi3 or Go, whereas depletion of CRIP1a significantly increased activation of these $\mathrm{G}$ proteins. Concurrently, over-expression of CRIP1a led to a robust activation of Gi1 or Gi2 in response to CP55940. Both CP55940-mediated inhibition of cAMP accumulation as well as CP55940-driven ERK phosphorylation were accentuated by CRIP1a depletion [18]. At the level of cAMP regulation, the depletion of CRIP1a resulted in a left-shift of the log dose-response curve for CP55940, allowing the inhibition of cAMP to occur at much lower concentrations of agonist [18]. Initial (phase I) phosphorylation of ERK is governed by cAMP levels, as well as by release of $\beta \gamma$ subunits from $\mathrm{Gi} / \mathrm{o}$ proteins and interaction with integrins and receptor tyrosine kinases [22]. As endogenous levels of CRIP1a curtail agonist-mediated inhibition of cAMP production, the increased protein kinase A (PKA) 
activity leads to inactive src or raf, and thereby reduced ERK phosphorylation. When endogenous CRIP1a levels are depleted, cAMP levels and PKA activity are reduced, and ERK phosphorylation is increased, consistent with the data observed [18].

The $\mathrm{CB}_{1}$ receptor exists as a functional complex with Gi/o proteins in CHAPS detergent, which theoretically extracts lipid raft in addition to plasma membrane proteins [23]. This complex can be dissociated with non-hydrolyzable GTP analogs such as GTP $\gamma \mathrm{S}$, and by $\mathrm{CB}_{1}$ agonists with a significant degree of agonist selectivity $[24,25]$. In immunoprecipitations of the $\mathrm{CB}_{1}-\mathrm{G}$ protein complex from brain or N18TG2 membranes, peptides mimicking the juxtamembrane C-terminal of the $\mathrm{CB}_{1}$ receptor could compete for binding to $\mathrm{G} \alpha \mathrm{i} 3$ and $\mathrm{G} \alpha \mathrm{o}$ proteins. The competing peptides encompass the Helix 8 and the Cys415 palmitoylation site (Figure 1), suggesting that this domain is important for Gi3 and Go activation [25-27]. The juxtamembrane C-terminal peptide can function as an activator of Gi/o proteins in intact cells as a result of its conformation as an amphipathic helix which facilitates membrane crossing [28,29]. In contrast, competition by peptides from the intracellular loop 3 (ICL3) indicated

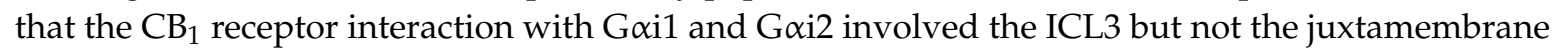
$\mathrm{C}$-terminal [30]. The direct association of $\mathrm{CB}_{1}$ receptor-Gi/o protein subtypes were subject to differential regulation by structurally different classes of agonists [24,30,31], suggesting a means of regulating efficacy by the $\mathrm{CB}_{1}$ receptor selection of its $G$ protein partner.

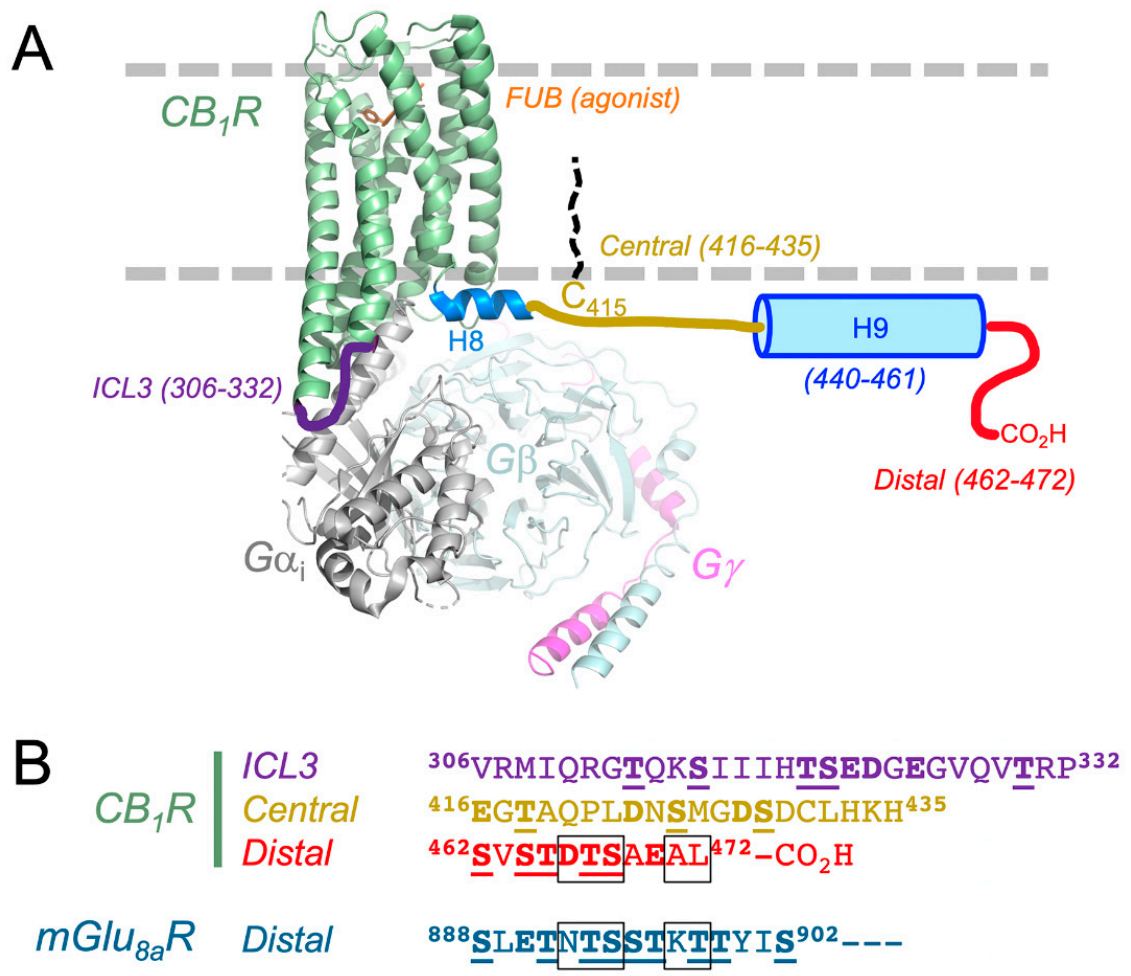

Figure 1. (A). Overview of the known structural and biochemical features of the $\mathrm{CB}_{1}$ receptor. The complex between full-length $\mathrm{CB}_{1}$ receptor, agonist MDMB-fubinaca (FUB), and $\mathrm{G}$ protein complex, as determined by cryoelectron microscopy (PDB code 6N4B) [32]. The intracellular region interactions are highlighted. Importantly, similar to available crystal structures, no electron density was observed for ICL3 and the C-terminus (residues 412-472). The nuclear magnetic resonance study by Ahn and colleagues supports that residues 440-461 form a second amphipathic helix that can interact with the membrane [33]. Cys415 can be palmitoylated to help anchor the C-terminus to the membrane [34,35]. (B). Primary sequence of the human $\mathrm{CB}_{1}$ receptor ICL3 loop, and C-terminal central and distal regions. The sequence is depicted in the same coloring as Figure 1A. Residues that can be phosphorylated are indicated in bold and underlined. Negatively-charged amino acids are indicated in bold. Five residues in the distal regions of the $\mathrm{CB}_{1}$ and $\mathrm{mGlu}_{8 \mathrm{a}}$ receptors important for CRIP1a binding are boxed in black (see text for details). 


\section{2. $\beta$-Arrestins and Internalization of the $C B_{1}$ Receptor}

CRIP1a functions to diminish cell surface $C_{1}$ receptor density without altering total $C_{1}$ protein expression in N18TG2 neuroblastoma cells [18]. CRIP1a plays a role in $\mathrm{CB}_{1}$ receptor plasma membrane trafficking. $\mathrm{CP} 55940$ or WIN55212-2 reduced cell surface $\mathrm{CB}_{1}$ receptors via a dynamin- and clathrin-dependent internalization process [19]. CRIP1a over-expression attenuated the agonist-induced internalization of cell surface $\mathrm{CB}_{1}$ receptors, agonist-induced aggregation of transiently-expressed green fluorescent protein- $\mathrm{CB}_{1}$ receptors, and $\mathrm{CP} 55940$-mediated $\beta$-arrestin recruitment to punctae aggregates. Conversely, CRIP1a knock-down augmented agonist-mediated $\beta$-arrestin redistribution to punctae [20]. CP55940-mediated internalization of $\mathrm{CB}_{1}$ receptors was followed by a cycloheximide-sensitive recovery of surface receptors (30-120 min), suggesting the requirement for new protein synthesis. In contrast, WIN55212-2-mediated loss of cell surface $C_{1}$ receptors recovered only in CRIP1a-knockdown cells. These findings suggest an agonist bias in CRIP1a regulation of $\mathrm{CB}_{1}$ receptor trafficking from Golgi-endoplasmic reticulum to the plasma membrane.

Co-immunoprecipitation studies indicated that $\mathrm{CB}_{1}$ receptors associate in complexes with either CRIP1a or $\beta$-arrestin [20]. However, CRIP1a and $\beta$-arrestin fail to co-immunoprecipitate with each other. This suggests a competition by CRIP1a and $\beta$-arrestin for binding to the $C_{1}$ receptor, which could explain how CRIP1a attenuates the action of $\beta$-arrestin to mediate $\mathrm{CB}_{1}$ receptor internalization.

\section{Structure of $\mathrm{CB}_{1}$ Receptor and CRIP1a Interactions}

\section{1. $C B_{1}$ Receptor Structure: What is Known About How CRIP1a Interacts?}

Several recent structural studies have dramatically improved our understanding of the $\mathrm{CB}_{1}$ receptor (see comprehensive review [36]). Two antagonist/inverse agonist crystal structures (taranabant, AM6538) revealed the first look at the protein in an inactive conformation $[37,38]$. The canonical 7-helical bundle is flanked perpendicularly by the amphipathic Helix 8 (Figure 1). The ligands bind within the orthosteric pocket, similar to the complexes of other class A GPCRs. The agonist AM11542 was developed and enabled the capture of the active conformation of the $\mathrm{CB}_{1}$ receptor [39]. The latter study identified a number of positional changes of many of the transmembrane helices and their associated extracellular and intracellular loops, resulting in a $\sim 53 \%$ reduction in the volume of the ligand binding cavity. One important caveat of these studies is that the $\mathrm{N}$ - and $\mathrm{C}$-termini of the $\mathrm{CB}_{1}$ receptor were truncated, along with many other site-directed sequence changes and loop alterations. Nonetheless, the structural changes observed in the $\mathrm{CB}_{1}$ receptor give insight into the propagation of ligand binding to $G$ protein interactions and downstream signaling events.

Cryoelectron microscopy has subsequently been used to determine the complex between the full-length $\mathrm{CB}_{1}$ receptor, the synthetic agonist MDMB-fubinaca, and the Gi1 trimeric signaling complex (Figure 1) [32]. The positive allosteric modulator ZCZ-011 and the single-chain variable fragment of the monoclonal antibody scFv16 were used to further stabilize the complex for analysis. This study provides a rationale for the mechanism of $G$ protein coupling and activation. Differences between the way that the ICL2 interacts with the Ras domain of Gai1, when compared to other available nucleotide-free GPCR-G protein complexes, support the promiscuity of $C_{1} B_{1}$ receptors for $G \alpha_{s}$ and $G \alpha_{i}$. Importantly, despite using the full-length $\mathrm{CB}_{1}$ receptor protein, the $\mathrm{C}$-terminus was not visible in this structure.

With the use of circular dichroism and nuclear magnetic resonance spectroscopy, Ahn and colleagues [33] determined that the C-terminus of the $\mathrm{CB}_{1}$ receptor (residues $400-472$, human protein numbering) contains two amphipathic helices when present in dodecylphosphocholine micelles as a membrane mimetic. As shown in Figure 1, Helix 8 (H8) is present as a highly conserved motif in rhodopsin-like GPCRs and is observable in the crystal structures of the $\mathrm{CB}_{1}$ receptor that are currently deposited in the protein data bank [37,38]. Helix 9 is located between the central and distal regions [33]. These regions contain multiple Ser and Thr phosphorylation sites (Figure 1), recently described as a "bar code" [40]. 
The $\mathrm{CB}_{1}$ receptor $\mathrm{C}$-terminal region is critical for regulation of desensitization and receptor internalization in neurons and in cell models [41-45]. The $\mathrm{CB}_{1}$ receptor C-terminus possesses two separate domains functioning in signal desensitization versus receptor internalization [46-49], depicted in Figure 1A, with sequences in Figure 1B. Both domains possess Ser and Thr phosphorylation sites $[20,50,51] . \mathrm{CB}_{1}$ receptor-mediated desensitization of $\mathrm{G}$ protein-regulated potassium channel Kir3 [47] and glutamatergic neurotransmission [52] requires the $\mathrm{CB}_{1}$ receptor central C-terminal Ser426 and Ser430 targets of phosphorylation, and can be mediated by $\mathrm{G}$ protein receptor kinase 3 (GRK3) and $\beta$-arrestin2 [47,48]. Agonist-driven $\mathrm{CB}_{1}$ receptor internalization requires phosphorylation of the distal C-terminal patch of up to six Ser and Thr residues, recruitment of $\beta$-arrestin2, and mediation by clathrin and AP-2 [41,48]. In the N18TG2 cell model, phosphorylated central peptide competed for association with $\beta$-arrestin1; and phosphorylated central or distal peptides competed for association with $\beta$-arrestin2 [20].

Co-immunoprecipitation of $\mathrm{CB}_{1}$ receptor protein complexes demonstrated that either central or distal C-terminal peptides competed for the $\mathrm{CB}_{1}$ receptor association with CRIP1a [20]. These studies clearly demonstrate that phosphorylation of these sites determines whether CRIP1a or $\beta$-arrestins can associate with the $\mathrm{CB}_{1}$ receptor $[19,20]$. CRIP1a binds to the same regions of the receptor when in the unphosphorylated state $[19,20]$. It is also possible that residues in ICL3 may play a role in CRIP1a binding.

In addition to the need for the unphosphorylated form of the $\mathrm{CB}_{1}$ receptor for CRIP1a binding, a few studies have highlighted the importance of key residues within the $\mathrm{C}$-terminus of $\mathrm{CB}_{1}$ receptor. In the original yeast two-hybrid study that identified CRIP1a and its splice variant CRIP1b, the last nine amino acids of the $\mathrm{CB}_{1}$ receptor were required to maintain the interaction [10]. This study also tested a variety of truncation variants of CRIP1 and found that residues 34-110 could still bind to the $\mathrm{CB}_{1}$ receptor when expressed in yeast. $A$ more recent study by Mascia and colleagues showed that full-length CRIP1a (residues 1-164) and the 1-110 and 34-110 truncation variants could block internalization of $\mathrm{CB}_{1}$ receptors expressed in HEK293 cells [53]. These observations are consistent with CRIP1a blocking $\beta$-arrestin2 binding [20]. Moreover, a panel of $\mathrm{C}$-terminal truncation and alanine scanning variants of the $\mathrm{CB}_{1}$ receptor confirmed that the last nine amino acids, ${ }^{464}{ }^{\text {STDTSAEAL }}{ }^{472}$ (Figure 1B) were required for CRIP1a to prevent internalization [53]. The Ala-scan results, coupled with the testing of chimeras between the $\mathrm{CB}_{1}$ receptor and the mGlu $\mathrm{u}_{8 \mathrm{a}}$ metabotropic glutamate receptor, demonstrated that five residues within the distal region were the most important to block receptor internalization (see boxed residues in Figure 1). Interestingly, if the sequence for mGlu $\mathrm{u}_{8 \mathrm{a}}$ $\left({ }^{889}\right.$ NTSSTKT $\left.^{898}\right)$ was substituted with that of mGlu $_{8 b}\left({ }^{889}\right.$ NSKSSVD $\left.^{898}\right)$, CRIP1a was not able to block receptor internalization [53]. It is also intriguing to observe that CRIP1a was able to interact with the $\mathrm{mGlu}_{8 \mathrm{a}}$ receptor, despite this receptor having the apparent recognition sequence within the context of a more extended C-terminus. Better knowledge of the crystal structure of CRIP1a and its complex with the $\mathrm{CB}_{1}$ or $\mathrm{mGlu}_{8 \mathrm{a}}$ receptors in the future should provide significant clarity to these observations.

\subsection{Predicted Structure of CRIP1a}

The primary structure of CRIP1a has been identified and found to be highly conserved across species (Figure 2). However, there appears to be no amino acid sequence homology with other known proteins $[10,54,55]$. Due to the fact that there are currently no experimentally-determined structures of CRIP1a and CRIP1b, researchers have had to rely on ab initio modeling and in silico binding experiments in an attempt to develop and test hypotheses concerning the interaction between the $\mathrm{CB}_{1}$ receptor and CRIP1a/b. Computational studies on CRIP1a by Ahmed and colleagues [54] used a general strategy that included analysis of the protein sequence, and then used homology modeling to establish an ab initio model. The predicted model showed greatest structural homology with the protein guanine nucleotide dissociation inhibitor 2 (Rho-GDI2) [54,55]. The structure was energy minimized to satisfy chemical restraints and Ramachandran plot requirements. Rho-GDI2 structurally resembles a $\beta$-barrel protein, and is an important cell signaling molecule that regulates activation of the 
small G protein Rho [54]. It is important to remember, however, that given the low sequence identity (15.9\% and $25.7 \%$ sequence identity for CRIP1a and CRIP1b, respectively), the structure needs to be evaluated carefully. A subsequent study by Singh and colleagues confirmed the structure prediction for CRIP1a and extended the analysis to CRIP1b using similar methods [55].

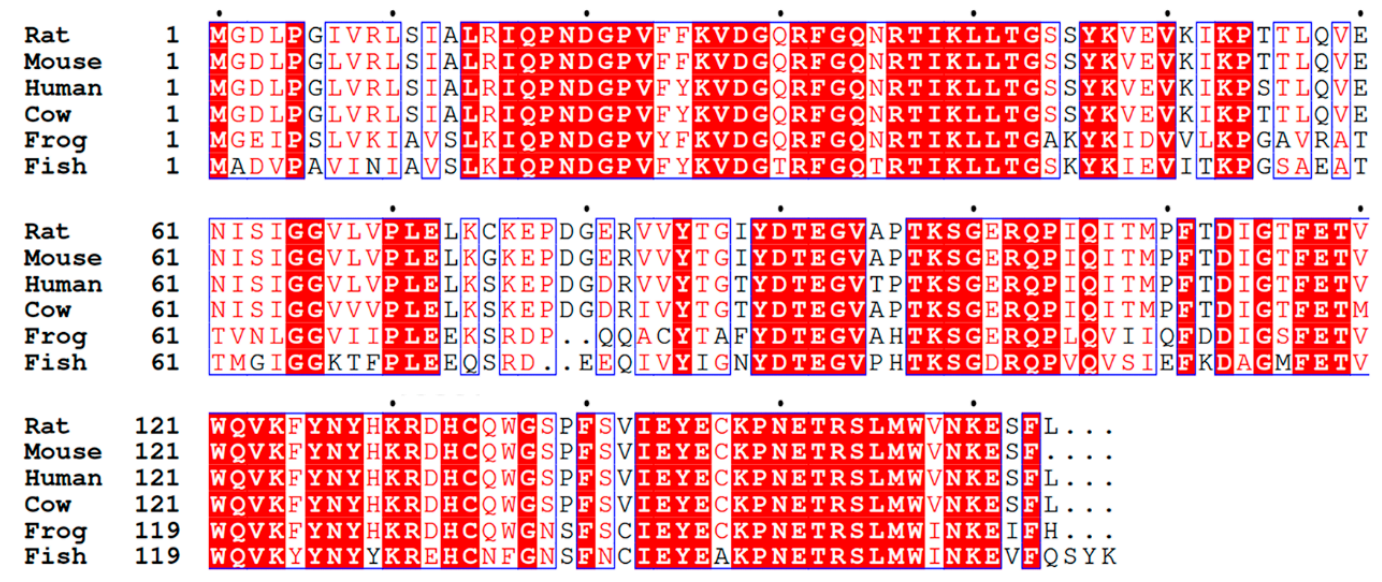

Figure 2. Primary sequence of CRIP1a from model organisms. Scientific names and protein codes: Rattus norvegicus (Q5M7A7), Mus musculus (Q5M8N0), Homo sapiens (Q96F85), Bos taurus (Q17QM9), Xenopus laevis (NP_001087998), Danio rerio (NP_001314699). The sequence identity relative to the top sequence proceeds down the alignment: $99 \%, 95 \%, 95 \%, 67 \%$, and $59 \%$.

Both groups then energy minimized the conformation of the $\mathrm{CB}_{1}$ distal $\mathrm{C}$-terminal 9-mer peptide (residues 464-472) and docked the peptide onto the CRIP1a/b model surface. Multiple potential binding sites were identified and then ranked. Ahmed and colleagues proposed that the CRIP1a residues Asn61, Lys76, Arg82, Tyr85, Lys124, and Lys130 made direct hydrogen bonds to the 9-mer peptide [54]. In particular, they highlighted that the Lys130 side chain nitrogen atom stabilizes the backbone conformation of Ser464, Thr465, and Asp466. Similar studies of CRIP1b predicted that the binding pocket for the $\mathrm{CB}_{1}$ C-terminus included residues Asn61, Ile64, Leu68, Glu77, Asp79, Arg82, Tyr85, Tyr89, Cys126, Tyr124, and Met128 [55]. Given the ambiguity of the potential binding sites, significantly more work is required to understand the structure of CRIP1a/b and how it interacts with the $\mathrm{CB}_{1}$ receptor.

\section{Conclusions}

Our understanding of functional modulation of the $\mathrm{CB}_{1}$ receptor by CRIP1a has implicated CRIP1a as a competitor with certain Gi/o protein subtypes (Gi3, Go), as well as both $\beta$-arrestins1 and 2. The recently-identified interaction of the $\mathrm{CB}_{1}$ receptor with $\mathrm{Gi1}$ can provide us with a greater understanding of how CRIP might function to promote $\mathrm{CB}_{1}$ receptor-Gi1 or Gi2 interactions. However, currently we still have a limited view of the totality of competitive interaction loci for Gi3, Go and the $\beta$-arrestins. Although the CRIP structure prediction results are promising, due to inconsistent evidence between the internalization assays and in silico analysis, continued efforts in structure determination by cryoelectron microscopy, x-ray crystallography, and/ or nuclear magnetic resonance could prove to be beneficial in providing a more detailed view of the $\mathrm{CB}_{1}$ receptor-CRIP1a interaction. A more accurate structure could provide greater insight and clarity into how the complete $\mathrm{CB}_{1}$ receptor intracellular surface could interact with CRIP1a.

CRIP1a has been linked to neuropathological states such as epilepsy and neurotoxicity in the hippocampus [11-14], schizophrenia phenotype [15,16], and motor dysfunction and addiction in the striatum [17], making the CRIP1a-CB $\mathrm{CB}_{1}$ receptor interaction an accessible target for novel drug design. This review focused on the structural interaction between the $\mathrm{CB}_{1}$ receptor and its association 
with CRIP1a. It is likely that this interaction will provide opportunities to develop either peptide "pepducins" or small molecule inhibitors specifically designed to modulate $\mathrm{CB}_{1}$ receptor function.

Author Contributions: Conceptualization, A.C.H.; Writing-original draft preparation, W.T.B., N.B.W., W.T.L. and A.C.H.; Writing-review and editing, W.T.B., N.B.W., W.T.L. and A.C.H.; Visualization and Graphics W.T.L.; Funding acquisition, A.C.H. and W.T.L.

Funding: This research was funded by the National Institutes of Health, grant number R01-DA042157.

Conflicts of Interest: The authors declare no conflict of interest.

\section{References}

1. Ligresti, A.; De, P.L.; Di Marzo, V. From phytocannabinoids to cannabinoid receptors and endocannabinoids: Pleiotropic physiological and pathological roles through complex pharmacology. Physiol. Rev. 2016, 96, 1593-1659. [CrossRef] [PubMed]

2. Howlett, A.C.; Barth, F.; Bonner, T.I.; Cabral, G.; Casellas, P.; Devane, W.A.; Felder, C.C.; Herkenham, M.; Mackie, K.; Martin, B.R.; et al. International union of pharmacology. XXVII. Classification of cannabinoid receptors. Pharm. Rev. 2002, 54, 161-202. [CrossRef] [PubMed]

3. Luongo, L.; Starowicz, K.; Maione, S.; Di Marzo, V. Allodynia lowering induced by cannabinoids and endocannabinoids (ALICE). Pharm. Res. 2017, 119, 272-277. [CrossRef] [PubMed]

4. Piscitelli, F.; Bradshaw, H.B. Endocannabinoid analytical methodologies: Techniques that drive discoveries that drive techniques. Adv. Pharm. 2017, 80, 1-30.

5. Howlett, A.C.; Abood, M.E. CB1 and CB2 receptor pharmacology. Adv. Pharm. 2017, 80, 169-206.

6. Howlett, A.C.; Blume, L.C.; Dalton, G.D. CB1 cannabinoid receptors and their associated proteins. Curr. Med. Chem. 2010, 17, 1382-1393. [CrossRef]

7. Smith, T.H.; Sim-Selley, L.J.; Selley, D.E. Cannabinoid CB1 receptor-interacting proteins: Novel targets for central nervous system drug discovery? Br. J. Pharm. 2010, 160, 454-466. [CrossRef]

8. Nie, J.; Lewis, D.L. The proximal and distal C-terminal tail domains of the CB1 cannabinoid receptor mediate G protein coupling. Neuroscience 2001, 107, 161-167. [CrossRef]

9. Nie, J.; Lewis, D.L. Structural domains of the CB1 cannabinoid receptor that contribute to constitutive activity and G-protein sequestration. J. Neurosci. 2001, 21, 8758-8764. [CrossRef]

10. Niehaus, J.L.; Liu, Y.; Wallis, K.T.; Egertova, M.; Bhartur, S.G.; Mukhopadhyay, S.; Shi, S.; He, H.; Selley, D.E.; Howlett, A.C.; et al. CB1 cannabinoid receptor activity is modulated by the cannabinoid receptor interacting protein CRIP 1a. Mol. Pharm. 2007, 72, 1557-1566. [CrossRef]

11. Ludanyi, A.; Eross, L.; Czirjak, S.; Vajda, J.; Halasz, P.; Watanabe, M.; Palkovits, M.; Magloczky, Z.; Freund, T.F.; Katona, I. Downregulation of the CB1 cannabinoid receptor and related molecular elements of the endocannabinoid system in epileptic human hippocampus. J. Neurosci. 2008, 28, 2976-2990. [CrossRef] [PubMed]

12. Monory, K.; Massa, F.; Egertova, M.; Eder, M.; Blaudzun, H.; Westenbroek, R.; Kelsch, W.; Jacob, W.; Marsch, R.; Ekker, M.; et al. The endocannabinoid system controls key epileptogenic circuits in the hippocampus. Neuron 2006, 51, 455-466. [CrossRef] [PubMed]

13. Bojnik, E.; Turunc, E.; Armagan, G.; Kanit, L.; Benyhe, S.; Yalcin, A.; Borsodi, A. Changes in the cannabinoid (CB1) receptor expression level and G-protein activation in kainic acid induced seizures. Epilepsy Res. 2012, 99, 64-68. [CrossRef] [PubMed]

14. Guggenhuber, S.; Alpar, A.; Chen, R.; Schmitz, N.; Wickert, M.; Mattheus, T.; Harasta, A.E.; Purrio, M.; Kaiser, N.; Elphick, M.R.; et al. Cannabinoid receptor-interacting protein Crip1a modulates CB1 receptor signaling in mouse hippocampus. Brain Struct. Funct. 2016, 221, 2061-2074. [CrossRef]

15. Perez, S.M.; Donegan, J.J.; Boley, A.M.; Aguilar, D.D.; Giuffrida, A.; Lodge, D.J. Ventral hippocampal overexpression of cannabinoid receptor interacting protein 1 (CNRIP1) produces a schizophrenia-like phenotype in the rat. Schizophr. Res. 2019, 206, 263-270. [CrossRef]

16. Xie, J.; Gizatullin, R.; Vukojevic, V.; Leopardi, R. The CCDC55 couples cannabinoid receptor CNR1 to a putative DISC1 schizophrenia pathway. Neuroscience 2015, 310, 723-730. [CrossRef] 
17. Blume, L.C.; Bass, C.E.; Childers, S.R.; Dalton, G.D.; Roberts, D.C.; Richardson, J.M.; Xiao, R.; Selley, D.E.; Howlett, A.C. Striatal CB1 and D2 receptors regulate expression of each other, CRIP1A and delta opioid systems. J. Neurochem. 2013, 124, 808-820. [CrossRef]

18. Blume, L.C.; Eldeeb, K.; Bass, C.E.; Selley, D.E.; Howlett, A.C. Cannabinoid receptor interacting protein (CRIP1a) attenuates CB1R signaling in neuronal cells. Cell Signal. 2015, 27, 716-726. [CrossRef]

19. Blume, L.C.; Leone-Kabler, S.; Luessen, D.J.; Marrs, G.S.; Lyons, E.; Bass, C.E.; Chen, R.; Selley, D.E.; Howlett, A.C. Cannabinoid receptor interacting protein suppresses agonist-driven CB1 receptor internalization and regulates receptor replenishment in an agonist-biased manner. J. Neurochem. 2016, 139, 396-407. [CrossRef]

20. Blume, L.C.; Patten, T.; Eldeeb, K.; Leone-Kabler, S.; Ilyasov, A.A.; Keegan, B.M.; O’Neal, J.E.; Bass, C.E.; Hantgan, R.R.; Lowther, W.T.; et al. Cannabinoid receptor interacting protein 1a competition with beta-arrestin for CB1 receptor binding sites. Mol. Pharm. 2017, 91, 75-86. [CrossRef]

21. Smith, T.H.; Blume, L.C.; Straiker, A.; Cox, J.O.; David, B.G.; McVoy, J.R.; Sayers, K.W.; Poklis, J.L.; Abdullah, R.A.; Egertova, M.; et al. Cannabinoid receptor-interacting protein 1a modulates CB1 receptor signaling and regulation. Mol. Pharm. 2015, 87, 747-765. [CrossRef] [PubMed]

22. Dalton, G.D.; Howlett, A.C. Cannabinoid CB1 receptors transactivate multiple receptor tyrosine kinases and regulate serine/threonine kinases to activate ERK in neuronal cells. Br. J. Pharm. 2012, 165, 2497-2511. [CrossRef] [PubMed]

23. Houston, D.B.; Howlett, A.C. Solubilization of the cannabinoid receptor from rat brain and its functional interaction with guanine nucleotide-binding proteins. Mol. Pharm. 1993, 43, 17-22.

24. Houston, D.B.; Howlett, A.C. Differential receptor-G-protein coupling evoked by dissimilar cannabinoid receptor agonists. Cell Signal. 1998, 10, 667-674. [CrossRef]

25. Mukhopadhyay, S.; McIntosh, H.H.; Houston, D.B.; Howlett, A.C. The CB(1) cannabinoid receptor juxtamembrane C-terminal peptide confers activation to specific G proteins in brain. Mol. Pharm. 2000, 57, 162-170.

26. Mukhopadhyay, S.; Howlett, A.C. CB1 receptor-G protein association. Subtype selectivity is determined by distinct intracellular domains. Eur. J. Biochem. 2001, 268, 499-505. [CrossRef]

27. Mukhopadhyay, S.; Cowsik, S.M.; Lynn, A.M.; Welsh, W.J.; Howlett, A.C. Regulation of Gi by the CB1 cannabinoid receptor $C$-terminal juxtamembrane region: Structural requirements determined by peptide analysis. Biochemistry 1999, 38, 3447-3455. [CrossRef]

28. Mukhopadhyay, S.; Shim, J.Y.; Assi, A.A.; Norford, D.; Howlett, A.C. CB(1) cannabinoid receptor-G protein association: A possible mechanism for differential signaling. Chem. Phys. Lipids 2002, 121, 91-109. [CrossRef]

29. Eldeeb, K.; Leone-Kabler, S.; Blume, L.C.; Howlett, A.C. CB1 Receptor intracellular loop4 mutation modulates $\mathrm{G}$ protein activation and cAMP production in human neuroblastoma cells. Int. Cannabinoid Res. Soc. Symp. Cannabinoids 2014, 24, 35.

30. Mukhopadhyay, S.; Howlett, A.C. Chemically distinct ligands promote differential CB1 cannabinoid receptor-Gi protein interactions. Mol. Pharm. 2005, 67, 2016-2024. [CrossRef]

31. Eldeeb, K.; Leone-Kabler, S.; Howlett, A.C. CB1 cannabinoid receptor-mediated increases in cyclic AMP accumulation are correlated with reduced Gi/o function. J. Basic Clin. Physiol. Pharm. 2016, 27, 311-322. [CrossRef] [PubMed]

32. Krishna, K.K.; Shalev-Benami, M.; Robertson, M.J.; Hu, H.; Banister, S.D.; Hollingsworth, S.A.; Latorraca, N.R.; Kato, H.E.; Hilger, D.; Maeda, S.; et al. Structure of a signaling cannabinoid receptor 1-G protein complex. Cell 2019, 176, 448-458. [CrossRef] [PubMed]

33. Ahn, K.H.; Pellegrini, M.; Tsomaia, N.; Yatawara, A.K.; Kendall, D.A.; Mierke, D.F. Structural analysis of the human cannabinoid receptor one carboxyl-terminus identifies two amphipathic helices. Biopolymers 2009, 91, 565-573. [CrossRef] [PubMed]

34. Oddi, S.; Dainese, E.; Sandiford, S.; Fezza, F.; Lanuti, M.; Chiurchiu, V.; Totaro, A.; Catanzaro, G.; Barcaroli, D.; De, L.V.; et al. Effects of palmitoylation of Cys(415) in helix 8 of the $\mathrm{CB}(1)$ cannabinoid receptor on membrane localization and signalling. Br. J. Pharm. 2012, 165, 2635-2651. [CrossRef] [PubMed]

35. Oddi, S.; Totaro, A.; Scipioni, L.; Dufrusine, B.; Stepniewski, T.M.; Selent, J.; Maccarrone, M.; Dainese, E. Role of palmitoylation of cysteine 415 in functional coupling CB1 receptor to Galphai2 protein. Biotechnol. Appl. Biochem. 2018, 65, 16-20. [CrossRef]

36. Al-Zoubi, R.; Morales, P.; Reggio, P.H. Structural insights into CB1 receptor biased signaling. Int. J. Mol. Sci. 2019, 20, 1837. [CrossRef] 
37. Hua, T.; Vemuri, K.; Pu, M.; Qu, L.; Han, G.W.; Wu, Y.; Zhao, S.; Shui, W.; Li, S.; Korde, A.; et al. Crystal structure of the human cannabinoid receptor CB1. Cell 2016, 167, 750-762. [CrossRef]

38. Shao, Z.; Yin, J.; Chapman, K.; Grzemska, M.; Clark, L.; Wang, J.; Rosenbaum, D.M. High-resolution crystal structure of the human CB1 cannabinoid receptor. Nature 2016, 540, 602-606. [CrossRef]

39. Hua, T.; Vemuri, K.; Nikas, S.P.; Laprairie, R.B.; Wu, Y.; Qu, L.; Pu, M.; Korde, A.; Jiang, S.; Ho, J.H.; et al. Crystal structures of agonist-bound human cannabinoid receptor CB1. Nature 2017, 547, 468-471. [CrossRef]

40. Nobles, K.N.; Xiao, K.; Ahn, S.; Shukla, A.K.; Lam, C.M.; Rajagopal, S.; Strachan, R.T.; Huang, T.Y.; Bressler, E.A.; Hara, M.R.; et al. Distinct phosphorylation sites on the beta(2)-adrenergic receptor establish a barcode that encodes differential functions of beta-arrestin. Sci. Signal. 2011, 4, ra51. [CrossRef]

41. Gyombolai, P.; Boros, E.; Hunyady, L.; Turu, G. Differential beta-arrestin2 requirements for constitutive and agonist-induced internalization of the CB1 cannabinoid receptor. Mol. Cell Endocrinol. 2013, 372, 116-127. [CrossRef] [PubMed]

42. Nguyen, P.T.; Schmid, C.L.; Raehal, K.M.; Selley, D.E.; Bohn, L.M.; Sim-Selley, L.J. beta-arrestin2 regulates cannabinoid CB1 receptor signaling and adaptation in a central nervous system region-dependent manner. Biol. Psychiatry 2012, 71, 714-724. [CrossRef] [PubMed]

43. Rubino, T.; Vigano, D.; Premoli, F.; Castiglioni, C.; Bianchessi, S.; Zippel, R.; Parolaro, D. Changes in the expression of $\mathrm{G}$ protein-coupled receptor kinases and beta-arrestins in mouse brain during cannabinoid tolerance: A role for RAS-ERK cascade. Mol. Neurobiol. 2006, 33, 199-213. [CrossRef]

44. Breivogel, C.S.; Lambert, J.M.; Gerfin, S.; Huffman, J.W.; Razdan, R.K. Sensitivity to delta9tetrahydrocannabinol is selectively enhanced in beta-arrestin2 -/- mice. Behav. Pharm. 2008, 19, 298-307. [CrossRef] [PubMed]

45. Morgan, D.J.; Davis, B.J.; Kearn, C.S.; Marcus, D.; Cook, A.J.; Wager-Miller, J.; Straiker, A.; Myoga, M.H.; Karduck, J.; Leishman, E.; et al. Mutation of putative GRK phosphorylation sites in the cannabinoid receptor 1 (CB1R) confers resistance to cannabinoid tolerance and hypersensitivity to cannabinoids in mice. J. Neurosci. 2014, 34, 5152-5163. [CrossRef]

46. Jin, W.; Brown, S.; Roche, J.P.; Hsieh, C.; Celver, J.P.; Kovoor, A.; Chavkin, C.; Mackie, K. Distinct domains of the CB1 cannabinoid receptor mediate desensitization and internalization. J. Neurosci. 1999, 19, 3773-3780. [CrossRef]

47. Hsieh, C.; Brown, S.; Derleth, C.; Mackie, K. Internalization and recycling of the CB1 cannabinoid receptor. J. Neurochem. 1999, 73, 493-501. [CrossRef]

48. Daigle, T.L.; Kwok, M.L.; Mackie, K. Regulation of CB1 cannabinoid receptor internalization by a promiscuous phosphorylation-dependent mechanism. J. Neurochem. 2008, 106, 70-82. [CrossRef]

49. Daigle, T.L.; Kearn, C.S.; Mackie, K. Rapid CB1 cannabinoid receptor desensitization defines the time course of ERK1/2 MAP kinase signaling. Neuropharmacology 2008, 54, 36-44. [CrossRef]

50. Bakshi, K.; Mercier, R.W.; Pavlopoulos, S. Interaction of a fragment of the cannabinoid CB1 receptor C-terminus with arrestin-2. Febs Lett. 2007, 581, 5009-5016. [CrossRef]

51. Singh, S.N.; Bakshi, K.; Mercier, R.W.; Makriyannis, A.; Pavlopoulos, S. Binding between a distal C-terminus fragment of cannabinoid receptor 1 and arrestin-2. Biochemistry 2011, 50, 2223-2234. [CrossRef] [PubMed]

52. Kouznetsova, M.; Kelley, B.; Shen, M.; Thayer, S.A. Desensitization of cannabinoid-mediated presynaptic inhibition of neurotransmission between rat hippocampal neurons in culture. Mol. Pharm. 2002, 61, 477-485. [CrossRef] [PubMed]

53. Mascia, F.; Klotz, L.; Lerch, J.; Ahmed, M.H.; Zhang, Y.; Enz, R. CRIP1a inhibits endocytosis of G-protein coupled receptors activated by endocannabinoids and glutamate by a common molecular mechanism. J. Neurochem. 2017, 141, 577-591. [CrossRef] [PubMed]

54. Ahmed, M.H.; Kellogg, G.E.; Selley, D.E.; Safo, M.K.; Zhang, Y. Predicting the molecular interactions of CRIP1a-cannabinoid 1 receptor with integrated molecular modeling approaches. Bioorg. Med. Chem. Lett. 2014, 24, 1158-1165. [CrossRef] [PubMed]

55. Singh, P.; Ganjiwale, A.; Howlett, A.C.; Cowsik, S.M. In silico interaction analysis of cannabinoid receptor interacting protein 1b (CRIP1b) - CB1 cannabinoid receptor. J. Mol. Graph Model 2017, 77, 311-321. [CrossRef]

(C) 2019 by the authors. Licensee MDPI, Basel, Switzerland. This article is an open access article distributed under the terms and conditions of the Creative Commons Attribution (CC BY) license (http://creativecommons.org/licenses/by/4.0/). 